\title{
Effect of onion extract and hydrogen peroxide on Pseudomonas aeruginosa isolated from urinary tract infection
}

\author{
Mohammed Oudah Hamad
}

\section{Article Info}

Department of Ecology, Faculty of

Science, Kufa of University, Iraq.

For Correspondence:

charge979@yahoo.com

Received:

Accepted:

Available Online:

29 October 2016

16 November 2016

6 December 2016

ISSN: 2224-7750 (Online)

2074-2908 (Print)

DOI: 10.3329/bsmmuj.v9i4.30147

Cite this article:

Hamad MO. Effect of onion extract and

hydrogen peroxide on Pseudomonas

aeruginosa isolated from urinary tract

infection. Bangabandhu Sheikh Mujib

Med Univ J. 1016; 9: 205-207.

Available at:

www.banglajol.info

A Journal of Bangabandhu Sheikh Mujib Medical University, Dhaka, Bangladesh
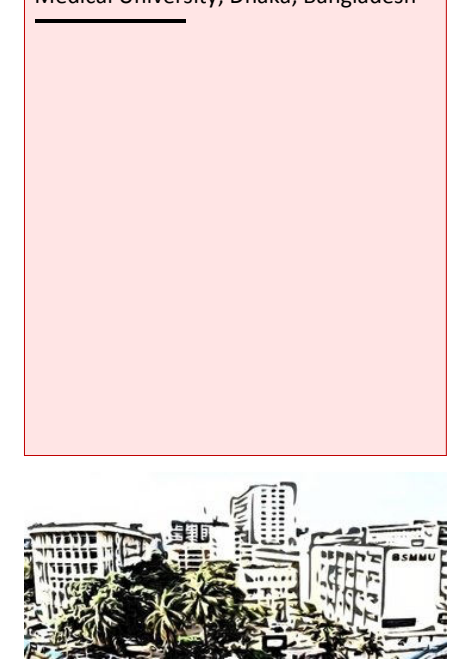

\section{Abstract} of $P$. aeruginosa.

\section{Introduction}

Urinary tract infection (UTI) is a common community-acquired bacterial disease, which frequently affect female outpatient. Pseudomonas aeruginosa is the most common member of the family Pseudomonas disease accounts of the majority of urinary tract infections.

Nosocomial acquired P. aeruginosa isolate tend to resistant to antimicrobial than do community -acquired strains, frequently displaying resistance to multiple classes of antimicrobial agents. However, development of resistance may occur during antimicrobial therapy and is particularly well documented during monotherapy, increasingly clear that resistance development in $P$. aeruginosa is multifactorial with mutations in genes encoding prions, efflux pumps, penicillin-binding proteins, and chromosomal beta-lactamase. 1 P. aeruginosa strains may contain extended-spectrum betalactamases, which degrade impanel.

Onion (Allium cepae) extracts possess an effect on all test bacterial strains and the effects were bactericidal.2

This study was designed to find out the antibacterial activity of onion and hydrogen peroxide combination on the multidrug resistant $P$. aeruginosa bacteria associated with urinary tract infection.
\end{abstract}

Antibacterial activity of the mixture of onion (Allium cepae) extract and hydrogen peroxide was tested on multidrug resistant isolate of Pseudomonas aeruginosa, obtained from biofilm on medical devices and urinary tract infection (UTI). P. aeruginosa exhibited high resistance rate toward sefitrixone and ciprofloxacin with inhibition zone of resistant of isolates in disc diffusion method was detected at 8 and $13 \mathrm{~mm}$, respectively. While inhibition zone of imipenem for the isolated bacteria was $20 \mathrm{~mm}$. Their decontamination was tested using a mixture of onion leaves aqueous extract $10.7 \%(\mathrm{w} / \mathrm{v})$ with $1.0 \%$ hydrogen peroxide. The mixture showed inhibition of the isolates. It can be concluded that a special antibacterial solution could eradicate multidrug resistant isolate

\section{Materials and Methods}

\section{Preparation of onion}

Fresh onion bulbs were surface sterilized using $70 \%$ alcohol and rinsed off thoroughly in distilled water and air dried, four bulbs of onion (107.5 g/L) were then blended. The resulting paste was allowed to stand for 24 hours. The juice was then filtered and squeezed out of it. The extract was stored below $4^{\circ} \mathrm{C}$. The liquid extract was mixed with $1.0 \%$ hydrogen peroxide to get the new invited antibacterial. The mixture was sterilized using autoclave at $121^{\circ} \mathrm{C}$ for $15 \mathrm{~min}$ and transferred into sterile flask.

\section{Disc diffusion test}

The Kirby-Bauer method was performed using a pure culture of previously identified bacterial organism. The inoculum to use in test was prepared by adding growth from 5 isolated colonies grown on blood agar to $5 \mathrm{~mL}$ of nutrients broth. This culture was then incubated for 2 hours to produce bacterial suspension of moderate turbidity which compared with turbidity of ready-made (0.5) McFarland. A sterile swab was used to obtain inoculum from standardized culture. This inoculum was swapped on Mueller-Hinton plate. The antibiotic disc was placed on the surface of the medium at evenly spread intervals with flamed forceps. Then incubated at $35^{\circ} \mathrm{C}$ for 24 hours, before reading results to identify cell's 
sensitivity..-4 The incubation period was $16-18$ hours when ciprofloxacin $(5 \mu \mathrm{g})$, sefotaxim $(30 \mu \mathrm{g})$ or impinem $10(\mu \mathrm{g})$ was used. Antibiotics inhibition zones were measured using transparent ruler. Zone size was compared to standard zone, $\underline{-}$ to determine the susceptibility of organisms to each antibiotic.

\section{Well diffusion method}

In this method, Muller-Hinton agar was prepared by equally cutting spaced well $(6 \mathrm{~mm})$. Then the plates were inoculated with a cotton swab dipping into screw tube containing a bacterial suspension and streaked over the surface of the plates. MullerHinton agar well was filled with $0.1 \mathrm{~mL}$ of prepared concentrations for each mixture (onion extract 32.5 $\mathrm{g} / \mathrm{L}$ and $1.0 \%$ hydrogen peroxide) and incubated the plates at $37^{\circ} \mathrm{C}$ for 24 hours. The susceptibility to this mixture was determined by measuring inhibition zone around well for concentration. $\underline{6}$

\section{Results}

Table I shows the antibiotic sensitivity test of multidrug resistant $P$. aeruginosa. The isolates of $P$. aeruginosa were resistant to sifitrixone (zone of inhibition: $8 \mathrm{~mm}$ ) and ciprofloxacin (zone of inhibition: $13 \mathrm{~mm}$ ) respectively, while the inhibition zone of $P$. aeruginosa in the disc diffusion test was determined at $20 \mathrm{~mm}$. The imipenem was the most effected antibiotics on
Table I

Sensitivity of multidrug resistant $P$. aeruginosa

\begin{tabular}{|l|r|}
\hline & Zone of inhibition \\
\hline $\begin{array}{l}\text { Ciprofloxacin }(5 \mu \mathrm{g}) \\
\text { Sefitrixon }(30 \mu \mathrm{g})\end{array}$ & $13 \mathrm{~mm}$ (Resistant) \\
$\begin{array}{l}\text { Imipenem }(10 \mu \mathrm{g}) \\
\text { Onion (Resistant) }\end{array}$ \\
$\begin{array}{l}\text { Hydrogen peroxide }(1 \%) \\
\text { g/L) }\end{array}$ & $9 \mathrm{~mm}$ (Sensitive) \\
$\begin{array}{l}\text { Onion (107.5 g/L) and } \\
\text { hydrogen peroxide }(1 \%)\end{array}$ & $23 \mathrm{~mm}$ (Sensitive) \\
\hline
\end{tabular}
isolates. The antagonistic action of the onion extracts, hydrogen peroxide and mixture of invited antibacterial solution, $P$. aeruginosa were resisted to the fresh onion extracts with the zone of inhibition of 12 $\mathrm{mm}$ and it was resistant to hydrogen peroxide with the zone of inhibition of $9 \mathrm{~mm}$. Moreover, $P$. aeruginosa was sensitive to the mixture (onion extracts with hydrogen peroxide) with the zone of inhibition of $23 \mathrm{~mm}$ in diameter.

\section{Discussion}

The multidrug resistant isolate of $P$. aeruginosa consider of the most important strains recovered from UTI showed the highest degree of resistance to most antibiotics and causing severe and relatively most serious infections.7 Zolotukhin et al. 2006 reported that most $P$. aeruginosa isolates were multiple resistance to antibiotic. The reasons for the resistance of the $B$-lactam antibiotics may attributed to the degradation of these antibiotics by $\beta$ lactamase enzymes, which is normally plasmid encoded, lack of penicillin binding protein for specific antibiotics, or due to the change of drug permeability.

In general $P$. aeruginosa is naturally less susceptible than other Gram negative bacilli to many antibiotics such as ampicillin, most cephalosporin and the macrolides. This is because of its relative ability to transport some antibiotics out of the cell preventing accumulation of antibiotic molecules and one type of mutation simultaneously comprises (penicillins, cephalosporins, fluoroquinolons, and tetracyclines) accelerating multidrug efflux. 9 Resistance of $P$. aeruginosa to quinolones is a chromosomal mediated process. No clinical isolates exhibiting plasmidmediated resistance has been reported. Resistance to quinolones can occur by mutation of the chromosomal genes that code for the gyrases another mechanism of resistance is impaired penetration of the outer membrane of the organism.

Hydrogen peroxide is an active agent which, affects a wide range of organisms like bacteria, yeast, fungi, viruses and spores. 10

Onion has recently been shown to have antibacterial, antifungal and anti-oxidant activities. In this study, the result was sensitive to the mixture onion extract and hydrogen peroxide. While the multidrug resistant isolate of $P$. aeruginosa was resistant to either onion extract or hydrogen peroxide. Stewart et al (2000) reported that effects onion extract on some pathogenic bacteria affecting ocular infections.11 Fresh onion extracts exhibited antagonistic on the test organisms ranging from observed zone of inhibition of $15 \mathrm{~mm}$ for Escherichia coli, $17 \mathrm{~mm}$ for Staphylococcus aureus, $20 \mathrm{~mm}$ for Streptococcus pyogenes and $8 \mathrm{~mm}$ for S. pneumoniae.

\section{Conclusion}

The mixture of the onion extract with hydrogen peroxide was effective to inhibit completely the multidrug resistant isolate of $P$. aeruginosa.

\section{Acknowledgement}

The author acknowledges the financial support of the College of Science of the University of Kufa. The author is grateful to Dr. Basim A. Almayahi, Department of Environment, College of Science, University of Kufa for assisting me throughout conducting the present research.

\section{References}

1. Hsueh PR, Chen ML, Sun CC, Chen WL, Pan HJ, 
Yang LS, Chang SC, Ho SW, Lee CY, Hsieh WC, Luh KT. Antimicrobial drug resistance in pathogens causing nosocomial infections at a University Hospital in Taiwan. Emerg Infect Dis. 2002; 8: 1981-99.

2. Cowan MM. Plant products as antimicrobial agents. Clinic Microbiol Rev. 2001; 12: 564-82.

3. Benson HJ. Microbiological applications laboratory manual in general microbiology. $8^{\text {th }}$ ed. The McGraw-Hill, 2001.

4. Shinkafi SA, Dauda H. Antibacterial activity of Allium cepa (onion) on some pathogenic bacteria associated with ocular infections. Sch J App Med Sci. 2013; 1: 147-51.

5. Clinical and Laboratory Standard Institute (CLSI). Performance standard for antimicrobial susceptibility testing. 20 ed. USA, 2010.

6. Ferguson D, Cahill OJ, Quilty B. Phenotypic, molecular and antibiotic profiling of nosocomial Pseudomonas aeruginosa strains isolated from two Irish Hospitals. J Med. 2007; 1.
7. Obritsch MO, Fish DN, Maclaren R, Jung R Nosocomial infec-tions due to multidrug resistant Pseudomonas aeruginosa: Epidemiology and treatment option. Pharmacotherapy 2005; 25: 1353 64.

8. Zolotukhin K, Abubakirova A, Popov M. Susceptibility to carbapenems of Pseudomonas spp. isolated from patients with ventilator associated pneumonia. 2006; 10: 103-17.

9. Friedrich LV, White RL, Bosso JS. Impact of use of multiple antimicrobials on changes in susceptibility of Gram-negative aerobes. Clin Infect Dis. 1999; 28: 1017.

10. Orrett FA, Davis GK. A comparison of antimicrobial suscepti-bility profile of urinary pathogens for the years, 1999 and 2003. J West Indian Med. 2006; 55: 95-99.

11. Stewart $P$, Roe F, Rayner J, Elkins JG, Lewandowski Z, Ochsner UA, Hassett DJ. Effect of catalase on hydrogen peroxide penetration into Pseudomonas aeruginosa biofilms. Appl Enviro Micro. 2000; 66: 836-38. 